American Journal of Pharmaceutical Education 2019; 83 (10) Article 7480.

\title{
RESEARCH
}

\section{Work Profile Factors Identified From the Career Pathway Evaluation Program, 2018 Pharmacist Profile Survey}

\author{
Jon C. Schommer, PhD, ${ }^{a}$ Elliott M. Sogol, $\mathrm{PhD},{ }^{\mathrm{b}}$ Lawrence M. Brown, $\mathrm{PhD}^{\mathrm{c}}$ \\ ${ }^{a}$ University of Minnesota, College of Pharmacy, Minneapolis, Minnesota \\ ${ }^{\mathrm{b}}$ Pharmacy Quality Solutions, Inc., Hillsborough, North Carolina \\ ${ }^{c}$ Chapman University, School of Pharmacy, Irvine, California \\ Submitted December 12, 2018; accepted April 19, 2019; published December 2019.
}

Objective. To identify work profile factors from the Career Pathway Evaluation Program, 2018 Pharmacist Profile Survey.

Methods. Exploratory factor analysis was used to describe the underlying structures (factors) that best represented respondents' work profiles. Descriptive statistics and Analysis of Variance were used to describe the 17 different work categories listed in the survey.

Results. Eleven underlying factors were identified for the respondents' work setting profiles. A description of these factors among the 17 different respondent career categories revealed variation that can be useful in describing the career categories in the APhA Career Pathway Evaluation Program for Pharmacy Professionals.

Conclusion. The results revealed variation among pharmacist career types. The profiles constructed in this study describe the characteristics of various career paths and can be helpful for decisions regarding educational, experiential, residency, and certification training in pharmacist careers.

Keywords: pharmacist, career, pathway, evaluation

\section{INTRODUCTION}

Evolving norms for the Doctor of Pharmacy (PharmD) degree and the proliferation of postdoctoral training for pharmacists ${ }^{1-7}$ have created recognized competencies in the pharmacy profession for taking on expanded responsibility for optimizing medication use in the US health care system. ${ }^{8-13}$ Pharmacists are faced with an array of choices regarding job positions and educational pathways that can enhance their chosen careers. ${ }^{14-20}$

To help individuals in the pharmacy profession learn about various career options that might fit their interests and skills, the Pathway Evaluation Program for Pharmacy Professionals was developed by Glaxo Pharmaceuticals in the 1980s. This program allowed individuals to match their interests and skills with career profiles to help determine which career options might be most suitable for them. The career profiles for the program were developed and updated through a series of surveys of respondents who worked in the career categories covered by the program. The initial Glaxo Pharmacy Specialty

Corresponding Author: Jon C. Schommer, University of Minnesota, College of Pharmacy, 308 Harvard St., SE, Minneapolis, MN 55455. Tel: 612-626-9915. Email: schom010@umn.edu.
Survey was conducted in fall 1988. In an effort to keep the information current, the Glaxo Pharmacy Specialty Sur$v e y$ was conducted again in spring $1993 .^{21}$

The developer and principal investigator of the Pathway Evaluation Program for Pharmacy Professionals worked with Glaxo Pharmaceuticals and the American Pharmacists Association to transition the program from being housed by a single pharmaceutical company to being housed by a national pharmacy association. By 2002, the program was maintained by the American Pharmacists Association, which conducted the 2002 Career Pathway Evaluation Program, Pharmacist Profile Survey to update the career profiles. The sampling frame for the survey was constructed by the American Pharmacists Association using lists from its own records, organizations that represented the career types, personal contacts, and advisory panels. The goal was to construct a sampling frame that represented pharmacists in each of the respondent categories used for the program. Findings from that survey were published as journal articles in 2003. ${ }^{22,23}$ The profile survey was repeated during $2007^{24,25}$ and again in $2012^{26}$ using a web-based data collection technique. Using the previous survey instruments and findings as guides, the profile survey was updated and administered again during the summer of 


\section{American Journal of Pharmaceutical Education 2019; 83 (10) Article 7480.}

2018. The current form of the program is available online at pharmacist.com.

The objectives for this study were to use a portion of the 2018 Pharmacist Profile Survey as a data source to investigate the underlying factor structure of respondents' practice profiles that were created using the 47 items in the survey and use the resulting factors to describe 17 different career pathways. The results can provide insight about the underlying factor structure of pharmacist careers in 2018 and can be used to describe various career paths that were open to pharmacists in 2018.

\section{METHODS}

The data source for this study was the APhA Career Pathway Evaluation Program for Pharmacy Professionals - 2018 Pharmacist Profile Survey. The survey consisted of five sections that collected information about respondents' primary work setting, work setting profile, workload and work activities, background information, and open-ended written comments regarding career choices and about the survey form. Data collected from section 2 of the survey, work setting profile, were used for this study. This section contained 47 items that asked respondents about the degree to which each work characteristic described their work setting. Each item was rated on a 10-point scale. The items were selected by an expert panel so that they would represent a broad range of career categories, from time spent performing physical assessments, to time spent conducting research, to time spent managing business operations. In addition, items were selected to cover several work setting facets. Items ranged from time spent in various activities (eg, patient care, management) to the extent that a respondent's work setting offered certain benefits (eg, job sharing, parental leave). This allowed for variation and depth of data that were necessary for creating career profiles within the Career Pathway program.

For the 2018 survey, a web-based data collection technique was used. Through a purposive sampling process, individuals who would likely fit one of the 17 career categories in the survey (Table 1) were identified by an expert panel. They convened via conference call on a regular basis for identifying and inviting potential respondents to participate. The expert panel also reviewed the 17 career categories to help ensure that the list not only built upon past work but was contemporary for current pharmacy practice. Both individual (eg, personal emails) and broadcast (eg, newsletters) invitations were used for recruiting survey respondents. Invitations were made from May 2018 through September 2018. On October 1, 2018 , the 1,046 survey forms that had been submitted were downloaded from the host site. Of these, 704 contained usable responses for all 47 items required for factor analysis and, therefore, were suitable for inclusion in the study.

For the first study objective, exploratory factor analysis was used to investigate the underlying factor structure of respondents' work profiles that were created using the 47 items in the survey. Factor analysis is used to understand the structure of a correlation matrix. It helps categorize a relatively large number of variables into a few overall factors. In this study, varimax rotation was used for factor analysis to maintain orthogonality (independence) of factors and to minimize the number of variables that had high $(>0.40)$ loadings on a factor. Only factors with eigenvalues greater than one were included in the factor solution. In addition, only items with factor loadings with absolute values $>0.4$ on one and only one factor were included for identifying factors. This was done to: maintain orthogonality (independence) among factors, establish parsimony (simplest statistical solution) in the application of the factors, and provide comprehensibility for interpretation of findings.

Scores for the overall factors were computed by summing the scores of the items that loaded on the corresponding factor. Each factor was assigned a name based upon the items that comprised that particular construct. Means, standard deviations, and measure reliabilities (Cronbach coefficient alpha) were computed for each factor. For factors comprised of only two items, both Cronbach coefficient alpha and Spearman correlations were computed for assessing reliability. ${ }^{27}$ For the second study objective, mean scores for the resulting factors were used to describe the 17 different career pathways listed in the survey. Analysis of variance was used to ascertain that mean scores for the factors differed significantly among the 17 career categories. Based on sample size requirements for estimating analysis of variance statistics, our goal was to have at least six respondents in each of the 17 categories to achieve a power of 0.8 for the comparisons.

\section{RESULTS}

Forty out of the 47 items in this study met our factor analysis criteria (loaded on a factor with an eigenvalue greater than one, exhibited a factor loading with an absolute value $>0.4$, and loaded on one and only one factor). Of the seven items that were dropped from analysis, four of them loaded on two factors and three did not have a factor loading $>0.4$ on any of the 11 resulting factors. Each factor was assigned a name based on the items that comprised that particular construct (factor analysis findings are available from the corresponding author). The 40 items that met our analysis criteria were grouped into 11 factors (income and benefits, stress and handling multiple 
American Journal of Pharmaceutical Education 2019; 83 (10) Article 7480.

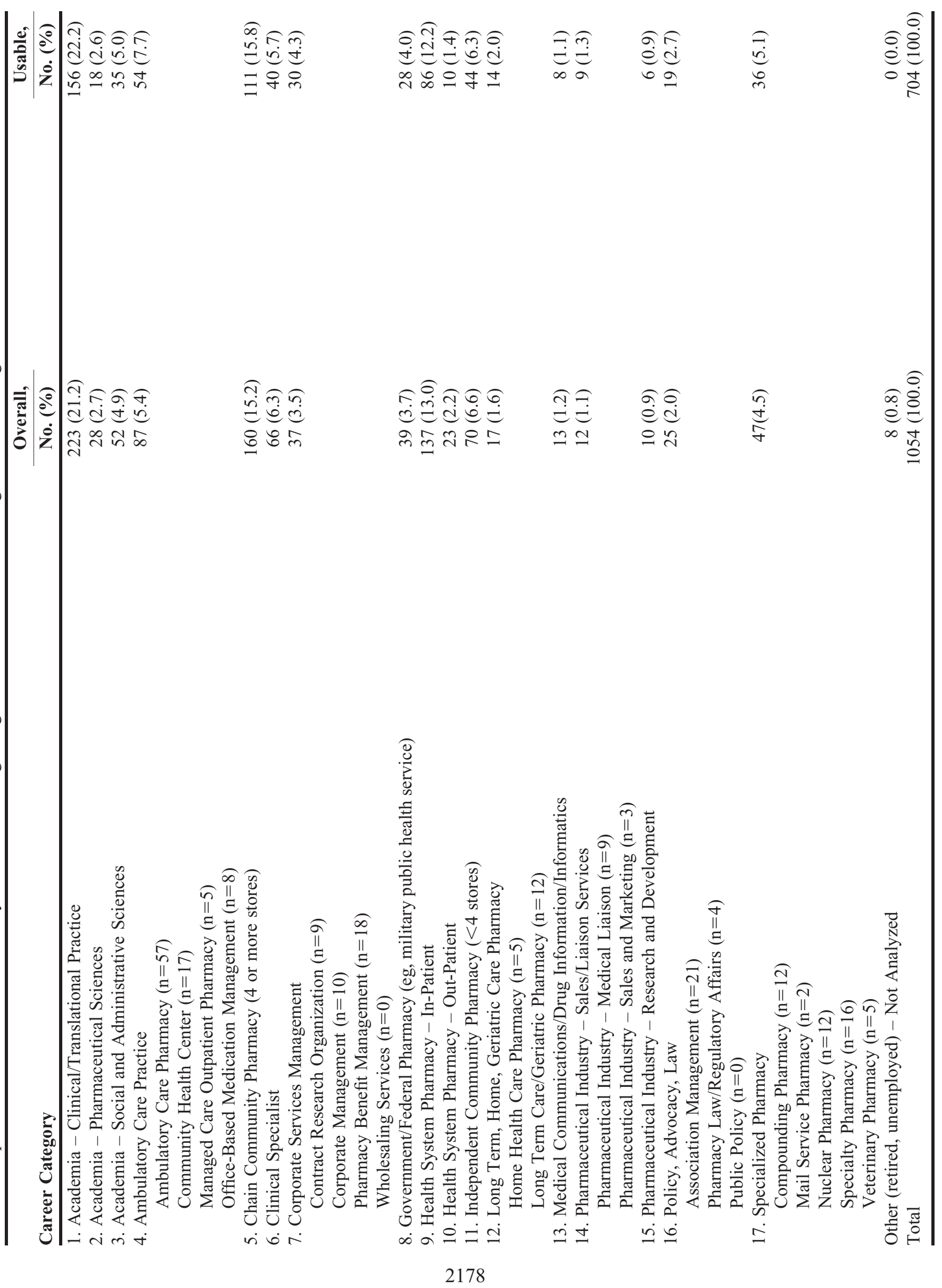




\section{American Journal of Pharmaceutical Education 2019; 83 (10) Article 7480.}

tasks, self-actualization, job position flexibility, additional training required, applying knowledge, unique focus, patient care, managerial responsibility, work schedule flexibility, research).

Table 2 summarizes the 11 factors we identified. Based on per-item means, the three highest scores for the overall group of respondents were for income and benefits (7.5), stress and handling multiple tasks (7.3), and selfactualization (6.7). The three lowest scores were for managerial responsibility (4.7), work schedule flexibility (3.7), and research (3.4). Per-item mean scores for each of the 11 identified factors were compared among the 17 respondent categories using analysis of variance. The results showed that, for each factor, there were significant differences in scores among career categories ( $p$ values $<.001)$.

The career categories with the highest four per-item mean scores for each factor are presented in Table 3. A complete summary of ANOVA results is available from the corresponding author. The career categories that scored highest on income and benefits were Pharm Industry - Research \& Development (9.1), Policy, Advocacy, Law (8.7), Medical Communications, Drug Information, Informatics (8.3), and Academic - Social and Administrative Sciences (8.2). For the factor stress and handling multiple tasks, the highest scoring career categories were Chain Community Pharmacy (8.5), Medical Communications, Drug Information, Informatics (8.5), Pharm Industry - Research \& Development (8.0), and Clinical Specialist (7.7).

For the factor self-actualization, highest scores were reported by respondents categorized as Academia-Social and Administrative Sciences (7.8), Policy, Advocacy,
Law (7.7), Academia-Clinical and Translational Practice (7.7), and Academic-Pharmaceutical Sciences (7.6). The highest scores for Job Position Flexibility (leave, free time, location) were: Pharm Industry-Sales \& Liaison Services (7.4), Academia-Social and Administrative Sciences (7.2), Medical Communications, Drug Information, Informatics (7.0), and Corporate Services Management (6.9).

For the factor indicating additional training was required, the highest scores were reported by respondents categorized as working in academia-pharmaceutical sciences (8.5), medical communications, drug information, informatics (7.8), pharm industry-sales \& liaison services (7.5), and pharm industry-research \& development (7.2). For applying knowledge (scientific, clinical, educational), the highest scoring career categories were clinical specialist (7.9), pharm industry-research \& development (7.1), ambulatory care practice (6.9), and health system pharmacy-inpatient (6.8).

The highest scores for unique focus were reported by medical communications, drug information, informatics (8.8), specialized pharmacy (8.1), policy advocacy, law (7.3), and clinical specialist (7.1). For the factor "patient care," scores were highest for ambulatory care practice (7.0), independent community pharmacy (6.9), chain community pharmacy (6.3), and health system pharmacyoutpatient (5.6).

Managerial responsibility scores were highest for chain community pharmacy (6.5), independent community pharmacy (6.2), health system pharmacy-outpatient (6.0), and policy, advocacy, law (5.7). Work schedule flexibility (part time, job share, exit/reentry) scores were highest for chain community pharmacy (4.9), independent

Table 2. Factor Summaries Generated from Analysis of Responses

\begin{tabular}{|c|c|c|c|c|c|c|}
\hline Factor Label & Items, No. & Per-Item Mean & Mean & SD & Range & Cronbach Coefficient Alpha \\
\hline Income and Benefits & 2 & 7.5 & 14.9 & 4.0 & $2-20$ & $0.61,0.42^{\mathrm{a}}$ \\
\hline Stress and Handling Multiple Tasks & 2 & 7.3 & 14.6 & 3.7 & $2-20$ & $0.60,0.44^{\mathrm{a}}$ \\
\hline Self-Actualization & 12 & 6.7 & 80.0 & 20.3 & $12-120$ & 0.89 \\
\hline $\begin{array}{l}\text { Job Position Flexibility } \\
\text { (leave, free time, location) }\end{array}$ & 3 & 6.6 & 19.7 & 6.0 & $3-30$ & 0.40 \\
\hline Additional Training Required & 2 & 6.3 & 12.5 & 5.3 & $2-20$ & $0.34,0.20^{\mathrm{a}}$ \\
\hline Unique Focus & 2 & 5.8 & 11.5 & 4.9 & $2-20$ & $0.56,0.37^{\mathrm{a}}$ \\
\hline Patient Care & 4 & 5.1 & 20.4 & 8.3 & $4-40$ & 0.73 \\
\hline Managerial Responsibility & 2 & 4.7 & 9.4 & 5.2 & $2-20$ & $0.78,0.63^{\mathrm{a}}$ \\
\hline $\begin{array}{l}\text { Work Schedule Flexibility } \\
\text { (part time, job share, exit/reentry) }\end{array}$ & 3 & 3.7 & 11.1 & 6.6 & $3-30$ & 0.64 \\
\hline
\end{tabular}

${ }^{a}$ Spearman correlation coefficient is reported in addition to Cronbach coefficient alpha for two-item factors. All correlations were significant $(p<.001)$ 
American Journal of Pharmaceutical Education 2019; 83 (10) Article 7480.

Table 3. Career Categories With the Highest Per-Item Mean Scores for Each Factor Generated from Analysis of Responses

\begin{tabular}{|c|c|c|c|c|}
\hline Factor Label & Highest & Second Highest & Third Highest & Fourth Highest \\
\hline Income and Benefits & $\begin{array}{l}\text { Pharm Industry - } \\
\text { Research \& } \\
\text { Development (9.1) }\end{array}$ & $\begin{array}{l}\text { Policy, Advocacy, Law } \\
\text { (8.7) }\end{array}$ & $\begin{array}{l}\text { Medical } \\
\text { Communications, } \\
\text { Drug Information, } \\
\text { Informatics (8.3) }\end{array}$ & $\begin{array}{l}\text { Academia - Social and } \\
\text { Administrative } \\
\text { Sciences }(8.2)\end{array}$ \\
\hline $\begin{array}{l}\text { Stress and Handling } \\
\text { Multiple Tasks }\end{array}$ & $\begin{array}{c}\text { Chain Community } \\
\text { Pharmacy (8.5) }\end{array}$ & $\begin{array}{l}\text { Medical } \\
\text { Communications, Drug } \\
\text { Information, } \\
\text { Informatics (8.5) }\end{array}$ & $\begin{array}{l}\text { Pharm Industry - } \\
\text { Research \& } \\
\text { Development (8.0) }\end{array}$ & Clinical Specialist (7.7) \\
\hline Self-Actualization & $\begin{array}{l}\text { Academia - Social and } \\
\text { Administrative } \\
\text { Sciences }(7.8)\end{array}$ & $\begin{array}{l}\text { Policy, Advocacy, Law } \\
\text { (7.7) }\end{array}$ & $\begin{array}{l}\text { Academia }- \text { Clinical \& } \\
\text { Translational } \\
\text { Practice }(7.7)\end{array}$ & $\begin{array}{l}\text { Academia - } \\
\text { Pharmaceutical } \\
\text { Sciences (7.6) }\end{array}$ \\
\hline $\begin{array}{l}\text { Job Position Flexibility } \\
\text { (leave, free time, } \\
\text { location) }\end{array}$ & $\begin{array}{c}\text { Pharm Industry - Sales \& } \\
\text { Liaison Services (7.4) }\end{array}$ & $\begin{array}{l}\text { Academia - Social and } \\
\text { Administrative } \\
\text { Sciences (7.2) }\end{array}$ & $\begin{array}{l}\text { Medical } \\
\text { Communications, } \\
\text { Drug Information, } \\
\text { Informatics (7.0) }\end{array}$ & $\begin{array}{l}\text { Corporate Services } \\
\text { Management (6.9) }\end{array}$ \\
\hline $\begin{array}{l}\text { Additional Training } \\
\text { Required }\end{array}$ & $\begin{array}{l}\text { Academia - } \\
\text { Pharmaceutical } \\
\text { Sciences (8.5) }\end{array}$ & $\begin{array}{l}\text { Medical } \\
\text { Communications, Drug } \\
\text { Information, } \\
\text { Informatics (7.8) }\end{array}$ & $\begin{array}{l}\text { Pharm Industry - Sales } \\
\text { \& Liaison Services } \\
\text { (7.5) }\end{array}$ & $\begin{array}{l}\text { Pharm Industry - } \\
\text { Research \& } \\
\text { Development (7.2) }\end{array}$ \\
\hline $\begin{array}{l}\text { Applying Knowledge } \\
\text { (scientific, clinical, } \\
\text { educational) }\end{array}$ & Clinical Specialist (7.9) & $\begin{array}{l}\text { Pharm Industry - } \\
\text { Research \& } \\
\text { Development (7.1) }\end{array}$ & $\begin{array}{c}\text { Ambulatory Care } \\
\text { Practice (6.9) }\end{array}$ & $\begin{array}{l}\text { Health System } \\
\text { Pharmacy - Inpatient } \\
\text { (6.8) }\end{array}$ \\
\hline Unique Focus & $\begin{array}{l}\text { Medical } \\
\text { Communications, } \\
\text { Drug Information, } \\
\text { Informatics (8.8) }\end{array}$ & $\begin{array}{l}\text { Specialized Pharmacy } \\
\text { (8.1) }\end{array}$ & $\begin{array}{l}\text { Policy, Advocacy, Law } \\
\text { (7.3) }\end{array}$ & $\begin{array}{l}\text { Clinical Specialist } \\
\text { (7.1) }\end{array}$ \\
\hline Patient Care & $\begin{array}{c}\text { Ambulatory Care } \\
\text { Practice (7.0) }\end{array}$ & $\begin{array}{l}\text { Independent Community } \\
\text { Pharmacy (6.9) }\end{array}$ & $\begin{array}{c}\text { Chain Community } \\
\text { Pharmacy (6.3) }\end{array}$ & $\begin{array}{l}\text { Health System } \\
\text { Pharmacy - } \\
\text { Outpatient (5.6) }\end{array}$ \\
\hline $\begin{array}{l}\text { Managerial } \\
\text { Responsibility }\end{array}$ & $\begin{array}{c}\text { Chain Community } \\
\text { Pharmacy (6.5) }\end{array}$ & $\begin{array}{l}\text { Independent Community } \\
\text { Pharmacy }(6.2)\end{array}$ & $\begin{array}{l}\text { Health System } \\
\text { Pharmacy - } \\
\text { Outpatient (6.0) }\end{array}$ & $\begin{array}{l}\text { Policy, Advocacy, Law } \\
\text { (5.7) }\end{array}$ \\
\hline $\begin{array}{l}\text { Work Schedule } \\
\text { Flexibility (part time, } \\
\text { job share, exit/ } \\
\text { reentry) }\end{array}$ & $\begin{array}{c}\text { Chain Community } \\
\text { Pharmacy (4.9) }\end{array}$ & $\begin{array}{l}\text { Independent Community } \\
\text { Pharmacy }(4.5)\end{array}$ & $\begin{array}{l}\text { Pharm Industry - } \\
\text { Research \& } \\
\text { Development (4.2) }\end{array}$ & $\begin{array}{l}\text { Health System } \\
\text { Pharmacy - Inpatient } \\
\text { (4.1) }\end{array}$ \\
\hline $\begin{array}{l}\text { Research (including } \\
\text { writing and travel) }\end{array}$ & $\begin{array}{l}\text { Pharm Industry - } \\
\text { Research \& } \\
\text { Development (6.4) }\end{array}$ & $\begin{array}{c}\text { Pharm Industry - Sales \& } \\
\text { Liaison Services (5.2) }\end{array}$ & $\begin{array}{l}\text { Academia - } \\
\text { Social and } \\
\text { Administrative } \\
\text { Sciences (5.0) }\end{array}$ & $\begin{array}{l}\text { Corporate Services } \\
\text { Management (4.7) }\end{array}$ \\
\hline
\end{tabular}

community pharmacy (4.5), pharm industry-research \& development (4.2), and health system pharmacy-inpatient (4.1) respondents. For research (including writing and travel), the highest scores were reported by pharm industryresearch \& development (6.4), pharm industry-sales and liaison services (5.2), academia-social and administrative sciences (5.0), and corporate services management (4.7).

For historical context, Table 4 displays a comparison of the six factors identified in the 2002 survey $^{22}$ with the 10 factors identified in the 2007 survey $^{25}$, the 11 factors identified in the 2012 survey, ${ }^{26}$ and the 11 factors identified in the 2018 survey. The 2018 findings reveal how career pathways for pharmacy professionals are evolving over time. For example, the per-item means for patient care were 4, 4.7, and 5.1 in 2007, 2012, and 2018, respectively.

\section{DISCUSSION}

The results of this study provide insight about the underlying factor structure of the 47 items in the $\mathrm{APhA}$ 


\section{American Journal of Pharmaceutical Education 2019; 83 (10) Article 7480.}

Table 4. Comparison of Factors Identified in the 2002, 2007, 2012, and 2018 Studies Conducted as Part of the Pharmacist Profile Surveys in Each Respective Year

\begin{tabular}{|c|c|c|}
\hline Factor Labels & Items, No. & Per-Item Mean $^{a}$ \\
\hline \multicolumn{3}{|l|}{2002 Factor Label } \\
\hline Non-Salary Compensation & 4 & 7.2 \\
\hline Workload & 3 & 6.7 \\
\hline Future Innovation and Job Fulfillment & 12 & 6.5 \\
\hline Freedom & 2 & 5.7 \\
\hline Relational & 3 & 5.2 \\
\hline Translating Knowledge to Pharmacy Practice & 7 & 4.7 \\
\hline \multicolumn{3}{|l|}{2007 Factor Label } \\
\hline Security & 2 & 8.2 \\
\hline Stress & 2 & 7.2 \\
\hline Self-Actualization & 10 & 6.9 \\
\hline Geographic Location & 1 & 6.8 \\
\hline Application of Knowledge & 4 & 6.5 \\
\hline Managerial Responsibility & 4 & 5.2 \\
\hline Flexibility of Work & 4 & 5.0 \\
\hline Research & 5 & 4.6 \\
\hline Patient Care & 5 & 4.0 \\
\hline Dynamic Work Schedule & 4 & 3.9 \\
\hline \multicolumn{3}{|l|}{2012 Factor Label } \\
\hline Continuity of Co-Worker Relationships & 1 & 7.7 \\
\hline Stress & 2 & 7.2 \\
\hline Work Schedule Flexibility & 4 & 7.0 \\
\hline Self-Actualization & 9 & 6.7 \\
\hline Geographic Location & 1 & 5.7 \\
\hline Application of Clinical Knowledge & 3 & 5.4 \\
\hline Research & 5 & 5.4 \\
\hline Managerial Responsibility & 3 & 5.2 \\
\hline Innovation & 7 & 4.9 \\
\hline Patient Care & 4 & 4.7 \\
\hline Job Position Flexibility & 3 & 3.8 \\
\hline \multicolumn{3}{|l|}{2018 Factor Label } \\
\hline Income and Benefits & 2 & 7.5 \\
\hline Stress and Handling Multiple Tasks & 2 & 7.3 \\
\hline Self-Actualization & 12 & 6.7 \\
\hline Job Position Flexibility (leave, free time, location) & 3 & 6.6 \\
\hline Additional Training Required & 2 & 6.3 \\
\hline Applying Knowledge (scientific, clinical, educational) & 5 & 5.8 \\
\hline Unique Focus & 2 & 5.8 \\
\hline Patient Care & 4 & 5.1 \\
\hline Managerial Responsibility & 2 & 4.7 \\
\hline Work Schedule Flexibility (part time, job share, exit/reentry) & 3 & 3.7 \\
\hline Research (including writing and travel) & 3 & 3.4 \\
\hline
\end{tabular}

${ }^{a}$ Per-Item Means are ordered from highest to lowest

Career Pathway Evaluation Program for Pharmacy Professionals-2018 Pharmacist Profile Survey. The profiles constructed in this study could be helpful to individuals as they consider various career paths and as they choose focused experiences during their Doctor of Pharmacy training and postdoctoral training. For example, if a student pharmacist is interested in careers offering opportunities for patient care, the findings in Table 3 show that careers in ambulatory care practice, independent community pharmacy, chain community pharmacy, and health system pharmacy-outpatient areas score highest in this area. On the other hand, career pathways that scored highest for self-actualization were academiasocial and administrative sciences; policy, advocacy, 


\section{American Journal of Pharmaceutical Education 2019; 83 (10) Article 7480.}

law; academia-clinical and translational practice; and academia-pharmaceutical sciences.

The results can also be useful for educators who advise student pharmacists about various career options. For example, the findings in Table 3 could help match student interests with elective courses, introductory and advanced pharmacy practice experiences, research opportunities, and postdoctoral training options. In addition, the results can be used to identify new elective courses or practice experiences that might be needed for comprehensive and relevant pharmacy education. One of the reasons for periodically updating the profile for the Career Pathway program comes from acknowledging that not only do career opportunities change, but also that student pharmacists' priorities and desires for career pathways change. The findings from this research can be used as another piece of information for evaluating and developing curricula for pharmacy education to help meet those changing needs.

The limitations of this research should be kept in mind. First, non-coverage bias could exist. While great effort was devoted to identifying pharmacists and pharmaceutical scientists for the career categories in this study, the lists we developed were neither mutually exclusive nor exhaustive. Second, no explicit definitions were given for the career categories. Respondents applied their own interpretation to what a career category was and selected the most applicable to their work situation. The expert panel chose category names that were in common usage and that would resonate with respondents. Third, some categories had large sample sizes, while others had relatively small sample sizes. Based on sample sizes needed for conducting analysis of variance, we suggest that results for career categories with fewer than 14 responses should be viewed with caution. Fourth, because of the sample size limitations, we did not further categorize respondents by demographic variables such as gender, position, or years of experience. Future work could investigate how such demographic variables could affect the results. Fifth, respondents to this survey were identified and recruited using purposive sampling techniques (non-random). Therefore, results should not be used for making population estimates. Rather, our goal was to differentiate among the various career pathways we described. Sixth, the 47 items used for developing work profiles might not be an exhaustive list. However, the items provided information for describing pharmacy professional work profiles and various career options that were open to pharmacists in 2018. Finally, our findings are descriptive only and cannot be used to answer questions about why career pathways differ.
Previous research suggests that the 11 factors we identified could be associated with quality of work life, job stress, job satisfaction, career commitment, and job turnover intention. ${ }^{28,29}$ Although we did not study causal relationships, the Career Pathway Evaluation Program appears to contain descriptive items that would be useful to pharmacists who wish to learn more about factors that could impact the quality of their work life.

The findings also provide insight for future research in this area, particularly for the next Career Pathway Evaluation Program Profile Survey. We suggest that the 11 factors we identified could serve as useful categories for the Career Pathway Evaluation Program.

\section{CONCLUSION}

These findings serve as a useful summary for part of the Career Pathway Evaluation Program. We identified 11 underlying factors to the pharmacist profiles. Future research that investigates how representative these 11 factors and the underlying measurement items are to individuals who are seeking career guidance would be helpful in future updates.

The results also revealed variation among pharmacist career types. The profiles constructed in this study describe the characteristics of various career paths and can be helpful for decisions regarding educational, experiential, residency, and certification training in pharmacist careers.

\section{ACKNOWLEDGMENTS}

Funding for this study was provided by the American Pharmacists Association. The authors gratefully acknowledge Elizabeth Cardello and Gina Scime for serving on an expert advisory panel for this survey and for coordinating data collection.

\section{REFERENCES}

1. Chisholm-Burns MA, Gatwood J, Spivey CA. Economic analysis of obtaining a PharmD degree and career as a pharmacist. Am J Pharm Educ. 2015;79(8):Article 117.

2. Shah KS, Marwah U, Bundra K, et al. The PharmD/MD dualdegree program and its potential value in the pharmaceutical industry. Therapeutic Innov \& Reg Sci. 2016;50(6):839-845.

3. Deal EN, Stranges PM, Maxwell WD, et al. The importance of research and scholarly activity in pharmacy training.

Pharmacotherapy. 2016;36(2):e200-e205.

4. Copenhaver AM, Haver A, Pickering AJ, et al. Continuity of specialty pharmacy practice: a survey of PGY-2 pharmacy residency graduates. J Pharm Prac. https://doi.org/10.1177/

0897190018782016. Published June 13, 2018.

5. Stolpe SF, Adams AJ, Bradley-Baker LR, et al. Historical development and emerging trends of community pharmacy residencies. Am J Pharm Educ. 2011;75(8):Article 160. 


\section{American Journal of Pharmaceutical Education 2019; 83 (10) Article 7480.}

6. Kibicho J, Pinkerton SK, Owczarzak J. Community-based pharmacists' needs for HIV-related training and experience. $J$ Pharm Prac. 2014;27(4):369e378.

7. Gonzalvo JD, Kruckberg E, Newton ML. Advanced diabetes credentials for the community pharmacist: a pilot study. J Am Pharm Assoc. 2016;56(3):274e279.e3.

8. Dunn SP, Birtcher KK, Beavers CJ, et al. The role of the clinical pharmacist in the care of patients with cardiovascular disease. $J \mathrm{Am}$ College Cardiology. 2015;66(19):2129-2139.

9. Mossialos E, Courtin E, Naci H, et al. From "retailers" to health care providers: transforming the role of community pharmacists in chronic disease management. Health Policy. May 2015;119(5):628-39. doi: 10.1016/j.healthpol.2015.02.007. Epub February 18, 2015.

10. Dorsch MP, Lose JM, DiDomenico RJ. The effect of cardiovascular credentialed pharmacists on process measures and outcomes in myocardial infarction and heart failure.

Pharmacotherapy. 2014;34:803-808. 62.

11. Giberson SF. Million Hearts: Pharmacist-delivered care to improve cardiovascular health. Public Health Rep. 2013;128:2-6. 60. 12. Eckel RH, Jakicic JM, Ard JD, et al. 2013 AHA/ACC guideline on lifestyle management to reduce cardiovascular risk: a report of the American College of Cardiology/American Heart Association task force on practice guidelines. J Am Coll Cardiol. 2014;63: 2960-2984.

13. Schommer JC, Gaither CA, Doucette WR, Kreling DH, Mott DA. Pharmacist contributions to the US health care system reported in the 2009 and 2014 national pharmacist workforce surveys. Inov Pharm. 2015;6(2):Article 200. http://pubs.lib.umn.edu/innovations/vol6/iss2/5. 14. Ulbrich T, Adams A, Bright D, et al. Differences in career paths and attributes of pharmacists completing a community pharmacy residency program (CPRP). Inov Pharm. 2014;5(4):178.

15. Dikun JA, Crumby AS, Shahpurwala Z, Hall J, Charrois TL, Rosenthal MM. Understanding pharmacist success in practice: a scoping review. J Am Pharm Assoc. 2016;6(6):649-655.doi: 10.1016/ j.japh.2016.06.012. Epub September 28, 2016.

16. Rojanasarot S, Gaither CA, Schommer JC, Doucette WR, Kreling DH, Mott DA. Exploring pharmacists' perceived job alternatives: results from the 2014 National Pharmacist Workforce Survey. J Am Pharm Assoc. 2017;57(1):47-55. doi: 10.1016/ j.japh.2016.09.004. Epub November 9, 2016.

17. Hohmeier KC, Borja-Hart N, Cooper M, Kirby J, Fisher C. Training and retaining community pharmacy leaders: career pathways after completing a PGY1 community pharmacy residency affiliated with a large supermarket chain. $J$ Am Pharm Assoc. 2017;57(1):82-85. doi: 10.1016/j.japh.2016.08.013. Epub November 8, 2016.

18. Heavner MS, Tichy EM, Yazdi M. Implementation of a pharmacist career ladder program. Am J Health Syst Pharm. 2016;73(19):1524-30. doi: 10.2146/ajhp150615. Epub August 12, 2016.

19. Hager D, Chmielewski E, Porter AL, Brzozowski S, Rough SS, Trapskin PJ. Interprofessional development and implementation of a pharmacist professional advancement and recognition program. Am J Health Syst Pharm. 2017;74(22):1895-1902. doi: 10.2146/ajhp160792. 20. Bennett M, Goode JV. Recognition of community-based pharmacist practitioners: essential health care providers. J Am Pharm Assoc. 2016;56(5):580-583. doi: 10.1016/j.japh.2016.04.566. 21. Glaxo Wellcome Inc. Pathway Evaluation Program for Pharmacy Professionals. 4th ed. Research Triangle Park, NC; 1996. 22. Schommer JC, Brown LM, Millonig MK, Sogol EM. Career pathways evaluation program: 2002 pharmacist profile survey. Am J Pharm Educ. 2003;67(3):Article 79.

23. Brown LM, Millonig MK, Rothholz M, Schommer JC, Sogol EM. Career pathways for pharmacists. J Am Pharm Assoc. 2003;43:459-562.

24. Schommer JC, Sogol EM, Brown LM. Career pathways for pharmacists. J Am Pharm Assoc. 2007;47:563-564.

25. Schommer, JC, Brown LM, Sogol EM. Work profiles identified from the 2007 pharmacist and pharmaceutical scientist career pathway profile survey. Am J Pharm Educ. 2008;72(1):Article 2. 26. Schommer, JC, Sogol EM, Brown LM. Identifying work setting profile factors from the career pathway evaluation program. Am J Pharm Educ. 2013;77(9):Article 194.

27. Eisinga R, Grotenhuis MT, Pelzer B. The reliability of a twoitem scale: Pearson, Cronbach or Spearman-Brown? Int J Public Health. 2013;58(4):637-642. doi: 10.1007/s00038-012-0416-3. 28. Chui MA, Look KA, Mott DA. The association of subjective workload dimensions on quality of care and pharmacist quality of work life. Res Soc Admin Pharm. 2014;10(2):328-340.

29. Sexton JB, Schwartz SP, Chadwick WA, et al. The associations between work-life balance behaviours, teamwork climate and safety climate: cross-sectional survey introducing the work-life climate scale, psychometric properties, benchmarking data and future directions. BMJ Qual Saf. 2017;26:632-640. 